\title{
The Role of Geothermal Waters in Sustainable Development Application of Main North Center Algerian Hot Springs (Righa, Biban, Ksena)
}

\author{
A. Ait Ouali ${ }^{1,2}$, A. Issaadi ${ }^{2}$, A. Ayadi ${ }^{3}$ and K. Imessad ${ }^{1}$
}

\begin{abstract}
The study zone is one of the significant thermal waters in the north Algeria. It is characterized by a cold climate with intense rain rates $700 \mathrm{~mm} /$ year. The Jurassic geothermal reservoir system is exploited by thermal springs and traditional wells for agricultural purposes. The main reservoir lithology characterized by calcareous formations which yield the chemical features of highly mineralized $\mathrm{Na}-\mathrm{Cl}$ type representing the thermal waters. Seven main Hot springs was samples collected June 2018 with a temperature average between 29 and $80^{\circ} \mathrm{C}$ and conductivities range from 2520 to $3766 \mu \mathrm{S} / \mathrm{cm}$.For a better application of geothermal water sites, a multidisciplinary methods was adopted, geological site study, water chemistry and touristic impact for local economic development. In this study, a final map was realized of geothermal potential for possible exploitation of this clean energy
\end{abstract}

Keywords: Biban, thermal springs, sustainable development, geothermal use, water chemistry

\section{Introduction}

Since the most remote times, prehistoric man has been interested in hot springs and left witnesses of his wisdom. The Romans when they settle in Algeria will build thermal on the main hot springs. Agglomerations develop nearby such are: Aquac Calidae (Hammam Righa), Aquae Masa Castra ( Hammam Berrouaghia).

In addition to these major centers, it can be seen that at the level of the main hot springs, there are also Roman pools. It was not until 1970 that the local scientist focused on the study of thermal waters [1].

In addition, fossil fuels are more easily mobilized, which is interference to the development of other energies. However, in recent years, special attention has been paid to renewable alternative energies. The geothermal waters of the study zone are among the most famous Algerian hot Spas. They have been used for balneology and bathing [2]. The discharge temperature ranges between $22^{\circ} \mathrm{C}$ to $94^{\circ} \mathrm{C}$. The hottest springs are located in Guelma and Biban geothermal areas $\left(94^{\circ} \mathrm{C}, 80^{\circ} \mathrm{C}\right.$ respectively). These hot springs are associated with seismic active zones close to fault systems [3].

These conditions give rise to high geothermal potential [4]. Several thermal springs in the north of Algeria have been investigated by many authors [5-9]. However, geothermal potential, thermal springs temperature mapping, and reservoir temperature should be reinvestigated in all the identified geothermal sites in Algeria.

In March 2018, field work campaign was conducted in Righa and Biban geothermal provinces. Temperature, $\mathrm{pH}$ and flow rate have been measured in-situ. The temperature

${ }^{1}$ Centre de Développement des Energies Renouvelables, (CDER) BP 62 Route de l'Observatoire Bouzareah 16340 Algiers, Alegria

${ }^{3}$ Centre de Recherche en Astronomie Astrophysique et Géophysique, Algiers, Algeria 
was found ranging between $29^{\circ} \mathrm{C}$ and $80^{\circ} \mathrm{C}$. Geological conditions and thermal gradients show that central north part of Algeria is more likely favorable for the presence of geothermal reservoirs of medium to high temperatures [10]. In the present study, the objective is to better assess the main geothermal temperature class for the geothermal sites and to estimate the geothermal potential using geological field works and available hydrochemistry data. All results are represented in final global mapping for helping local authorities to continue using this renewable energy in sustainable development.

\section{General Aspect of the Study Area}

The Tellian Atlas extends from the littoral to the southern links of the Tell. The latter goes from Tiaret in the West to Sidi-Aissa in the East via Ksar el Boukhari. This ensemble is relayed to the south by the high inter-atlasic low lands located between the preceding domain and the Saharan Atlas which covers the eastern part. [11,11,13].

The study area is part of the Tellian Atlas, it is located in the north center of Algeria contains most important hot springs of the country (Righa, Biban, Ksena, Sidi-Yhaia and Ibainan ). This zone is limited to the North by the coastline, it extends from Ain defla in the west to Bejaia to the East and South by Bibanique barrier (Figure 1)

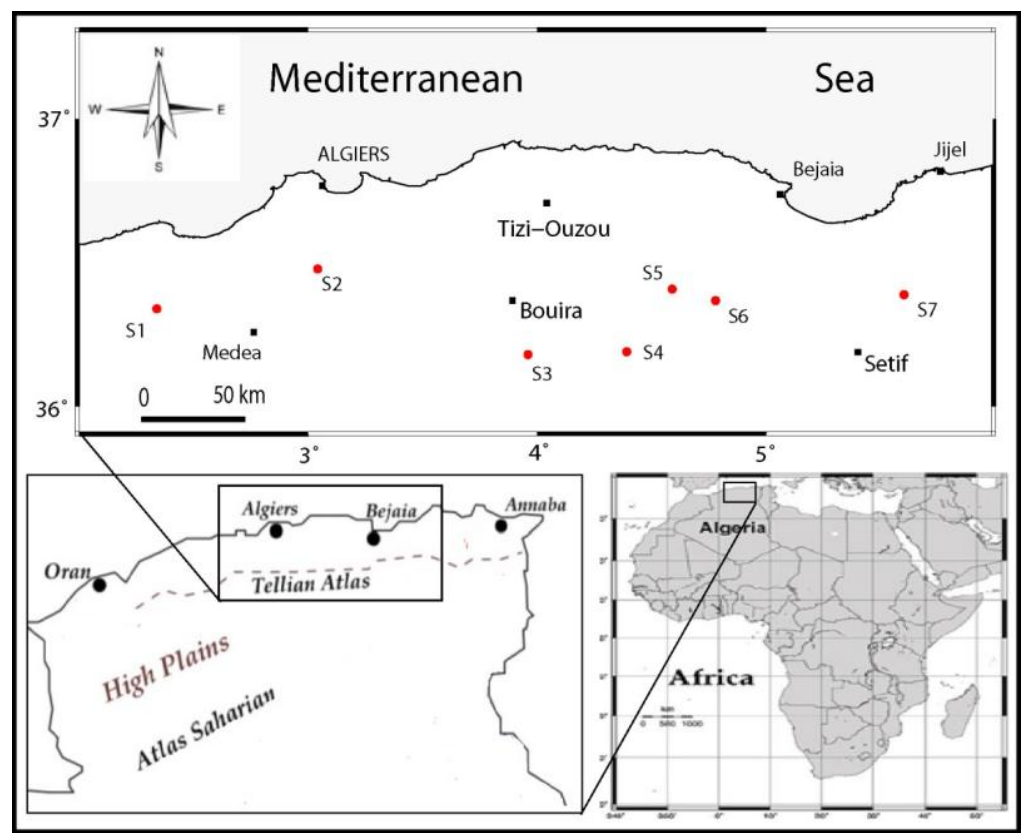

Figure 1. Location map of the study area

We distinguish the crystalline rocks and limestone chains in the study area, the crystalline formations are very developed in the East and only represented by some fragments very dispersed in the North of the Mitidja (Cape Matifou, Bouzareah, Chonoua). [14,14,16].

A huge limestone chain characterizes the eastern Tellian area (east of Algiers and Medea). This limestone litholgy located in high kabylie, culminates at $2308 \mathrm{~m}$ as high altitude 
mountain. The north of Algeria, and in particular the whole of Tell, is characterized by a significant rainfall.

The average rainfall recorded is relatively constant $(700 \mathrm{~mm})$. The remoteness of the sea and the decrease of altitude result in a lowering of the rainfall. Indeed, beyond the Bibanic barrier and Ouarsenis, a fairly clear decrease has been observed, with an average rainfall of about $500 \mathrm{~mm}$ [17].

\section{Methodology}

Seven main geothermal springs of north central Algeria were reinvestigated recently. During field work campaign (March 2018), physicochemical parameters such as water temperature, $\mathrm{pH}$, conductivity, TDS are measured using WTW multi-parameters (2C10-0011FB). Thermal water samples were collected into 500-ml polyethylene bottles, cleaned with distilled water before collecting the thermal fluid. Chemical analyses of thermal waters were performed at "hydrogeology laboratory of Algiers university".

For chemical plotting, the free software "Diagramme"-copyright, provided by Avignon hydrogeology laboratory (http://www.lha.univ-avignon.fr/LHA-Logiciels.htm), was used. Some maps were prepared using the public domain Generic mapping Tool (GMT) software [18].

Une campagne d'investigation sur le terrain pour la population local sur le rôle des stations thermales sur développement durable de la région, comme on aussi installé et aménagé des sites proche des sources chaude pour une production agricole chauffé à base de la géothermie afin de donner des récoltes hors saisons.

Throughout the fields investigation campaign some questions given for the local populations on the role of Spas on the region's sustainable development.

We managed some potential sites to geothermal energy exploitation in small economical projects near hot springs.

\section{Results and Discussion}

\subsection{Thermal waters chemistry of the study area}

The measurement of the physicochemical parameters (temperature, $\mathrm{pH}$ and conductivity) of the geothermal sites was lead in field campaign (2018). The temperature and chemical data of the geothermal sampling sites from the study area are listed in Table 1.

Table 1. Temperature and chemical data for main thermal springs in the study are

\begin{tabular}{llcccc}
\hline ID & Hot Springs & $\mathbf{T}\left({ }^{\circ} \mathbf{C}\right)$ & $\mathbf{p H}$ & TDS (mg/1) & Flow rate (1/s) \\
\hline S1 & Righa & 68 & 6,5 & 3520 & 2 \\
S2 & Melouan & 39 & 7,55 & 2052 & 4 \\
S3 & Kséna & 60 & 6,45 & 3302 & 10 \\
S4 & Biban & 80 & 6,52 & 14108 & 8 \\
S5 & Sidi-Yahia & 44 & 6,45 & 14770 & 28 \\
S6 & Ibainan & 60 & 6,69 & 13482 & 5 \\
S7 & Dahamcha & 29 & 7,2 & 2230 & 2 \\
\hline
\end{tabular}


The chemistry water type of thermal springs was done using Piper triangular ternary diagram (Figure 2). Most sampled waters are categorized by the supremacy of $\mathrm{Cl}_{-} \mathrm{SO}_{4}$ over $\mathrm{HCO}_{3}$, and $\mathrm{Na}-\mathrm{K}$ over $\mathrm{Ca}-\mathrm{Mg}$. Chemical analyses of the major elements for the ten hot spring samples are characterized by high concentration of $\mathrm{Na}^{+}$and $\mathrm{Cl}^{-}$with $\mathrm{pH}$ ranging from 6.45 to 7.55 and TDS oscillating between 2052 and $14770 \mathrm{mg} / \mathrm{l}$. The tendency near the chloride corner (saline hot spring type) is mainly the result of the dissolution of the evaporate rocks in the water.

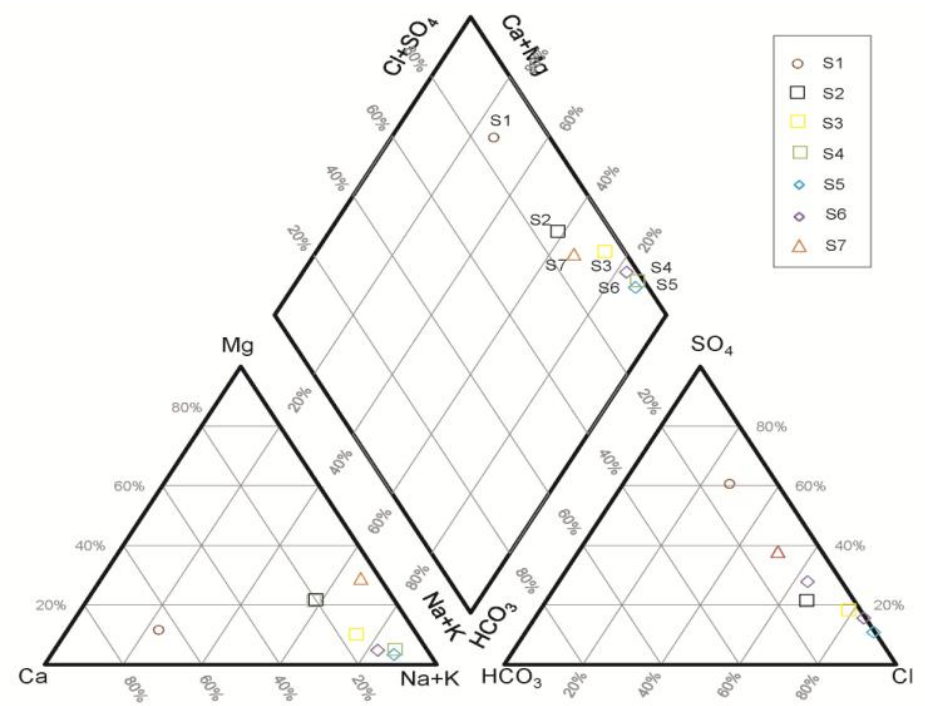

Figure 2. Piper diagram for hot springs from the study area (2018 campaign)

The calcium increase in the water is the result of reaction produced at high temperature between chlorinate-alkaline water and basalts.

\subsection{Geothermal potential map}

The geothermal potential was determinated for the samples. The distribution of thermal potential over the study area is in agreement with the variation of the water temperature measured at the surface (Figure 3).

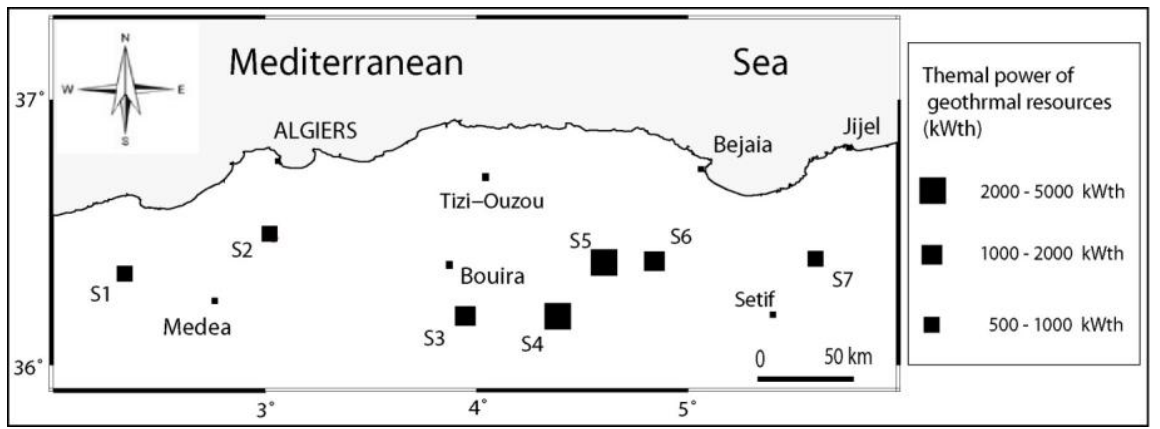

Figure 3. Geothermal potential location mapping 
High potential is observed in the central part of Biban region. Geothermal potential is calculated using the following equation (Eq 1) (Signorelli 2004):

$P=1000 \frac{\mathrm{Q}(\mathrm{T}-\mathrm{t})}{239}$

where $P$ is the potential geothermal power $\left(\mathrm{kW}_{\mathrm{th}}\right), Q$ is the discharge $(1 / \mathrm{s}), T$ is the initial temperature $\left({ }^{\circ} \mathrm{C}\right)$ and $t$ is the final temperature after cooling $\left({ }^{\circ} \mathrm{C}\right)$, arbitrarily fixed at $10^{\circ} \mathrm{C}$ [19].

Currently, geothermal resources are used in baths and Spas such those of the (S1), (S2), (S3) considered as the main Hammam (traditional bath) in the study area with temperature greater than $60^{\circ} \mathrm{C}$. The sites with high geothermal potential could be used in greenhouse heating and in touristic Spa. In North center area, an important geothermal resource (over $4000 \mathrm{kw}_{\text {th }}$ ) was calculated for the spring (S4 and S5).

\subsection{Geothermal exploitation and sustainable impact mapping}

Geothermal energy possible uses in Biban and Righa provinces are presented in Figure 4. Hot springs discharge temperatures range from 29 to $80{ }^{\circ} \mathrm{C}$ and the hottest spring temperature was measured near Biban area.

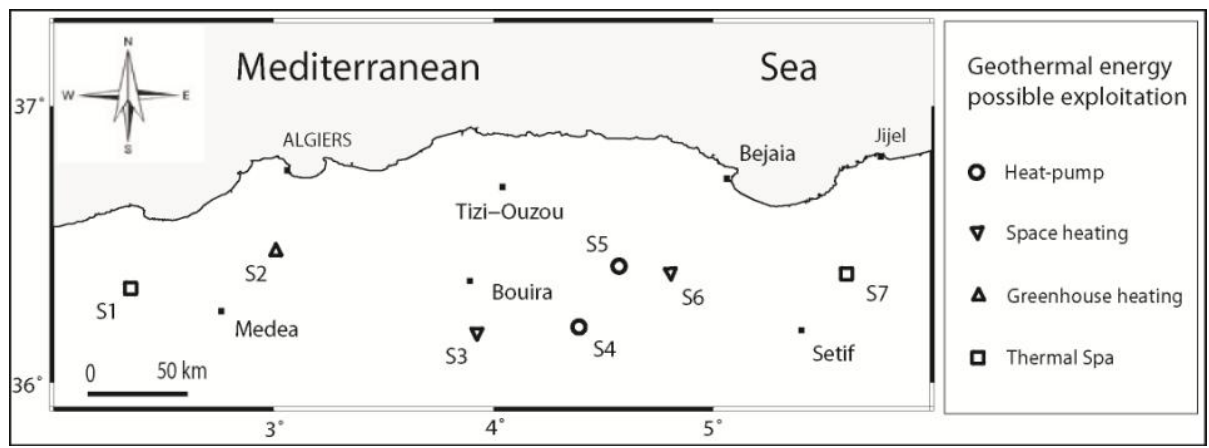

Figure 4. Geothermal exploitation and sustainable impact mapping

In this study, an inventory of seven (7) main hot springs was done. The hyper-thermal springs (temperatures over $45^{\circ} \mathrm{C}$ ) represented more than half sampling springs (S1, S3, S4 and S6). Ortho-thermal water temperatures range from 37 to $45^{\circ} \mathrm{C}$. Ortho-thermal waters are found in one geothermal springs (S5). The last class had temperature average between 22 to $37{ }^{\circ} \mathrm{C}$, represented by one geothermal discharge (S7). One global map was realized for geothermal energy possible use in to the Biban and Righa province. In the west part area (S1, S2 and S3), the direct use of geothermal energy was recommended for Spas, space and greenhouse heating. In the west part of the study zone (S4, S5, S6 and S7), a possible application of geothermal energy in heat pump and space heating.

\section{Conclusion}

The study of thermal water from Righa and Biban geothermal provinces was carried out in order to investigate the thermal water temperature and chemistry parameters. The physicochemical composition of seven thermal springs, with various 
methods such as fields works and Piper diagram was examined. The arrangement of major geochemistry elements has provided a comprehensive understanding of the mineralization processes that reinforce the geochemical evolution of the thermal water inside the study area. Combination of geological and hydrogeological methods highlighted a good relation between chemical processes and hydrothermal flow system. Data analysis showed that thermal waters in the study area come from geothermal Jurassic reservoir. Hydrochemistry results indicate that $70 \%$ of water samples are chloride sodic chemical types. A global mapping was performed to illustrate the geothermal potential and its possible uses in different economic sectors.

\section{Acknowledgments}

The authors are grateful to Prof. N. Yassaa, the Director of CDER to have supported our study. We are in debt to Dr. Farida Ousadou for her help to use GMT software.

\section{References}

[1] Verdeil, P., 1982, “Algerian thermalism in its geostructural setting. How hydrogeology

[2] Issaadi, A., 1992, "Le thermalisme dans son cadre géostructural, apports à la connaissance de la structure profonde de l'Algérie et de ses ressources géothermales," Thèse Doctorat en Sciences, University of Science and Technology Houari Boumedienne Algiers, Algeria.

[3] Meghraoui, M., 1988, "Géologie des zones sismiques du nord de l’Algérie, paléo-sismologie, Tectonique active et synthèse sismotectonique ," Thèse de Doctorat d'état, Université de Paris Sud, Orsay, Paris, France.

[4] Saibi, H., 2009, "Geothermal resources in Algeria," Renewable and Sustainable Energy Reviews 13 (9) 2544-2552.

[5] Takherist, D., and Lesquer, A., 1989, "Détermination du flux de chaleur en Algérie," Canadian Journal of Earth Sciences. 26, 615-626.

[6] Bouchareb-Haouchine, F.Z., and Boudoukha, A., 2009, "Hydrogeochemical and lithostructural approach of deep circulations in the mounts of Hodna Algeria," European journal of Scientific Research. ISSN 1450-216X. 37 (1) 12-20.

[7] Kedaid, F., 2002, "Algerian geothermal country report," Geothermal and Volcanological, Research Report of Kyushu University (11) 4-6.

[8] Fekraoui, A., and Kedaid, F., 2005, "Geothermal resources and uses in Algeria: a country updates report," Proceedings of the WGC, pages 1-8.

[9] Bouchareb-Haouchine, F.Z., 2012, "Etude Hydrochimique des Sources Thermales de l'Algérie du NordPotentialités Géothermiques," Thèse Doctorat en Sciences, University of Science and Technology Houari Boumedienne, Algiers, Algeria.

[10] Saibi, H., 2015, "Geothermal Resources in Algeria," Proceedings of the WGC, Australia-New Zealand pages 31-34.

[11] Kiken, M., 1975, "Étude géologique du Hodna, du Titteri et de la partie occidentale des Biban," Publ, Serv, Carte géol. Algérie, Série, (46) 217- 281.

[12] Bracène, R., 2002, “Géodynamique du Nord de l'Algérie : impact sur l'exploration pétrolière," Ph.D. dissertation, University of Cergy-Pontoise, France.

[13] Bracène, R., and Frizon, D., 2002, "The origin of intraplate deformation in the Atlas system of western and central Algeria: from Jurassic rifting to Cenozoic-Quaternary inversion," Tectonophysics (357) 207-226.

[14] Durand-Delga, M., and Fonboté, J.M., 1980, "Le cadre structural de la Méditerranée occidentale, géologie des chaînes alpines issues de la Téthys," Colloque no 5, 26॰ Congrès Géologique International, Mem, BRGM, Paris pp. 67-85. 
[15] Wildi, J. W., 1983, "La chaîne tello-rifaine (Algérie, Maroc, Tunisie): Structure, stratigraphie et évolution du Trias au Miocène," Rev, Géol, Dyn, Géogr Phys. 24, 201-297.

[16] Aïte, M.O., and Gélard, J. P., 1997, "Distension néogène post-collisionnelle sur le transect de GrandeKabylie (Algérie)," Bull, Soc, géol. France 168 (4) 423-436.

[17] Vila, J. M., 1980, "La chaine alpine d'Algérie orientale et des confins algéro-tunisiens," Thèse de Doctorat, Université de Pierre et Marie Curie, Paris, France.

[18] Wessel, P., Smith, H.F., 1998. New, improved version of the generic mapping tools released. EOS Trans. AGU 79, 579.

[19] Signorelli, S., 2004. Geoscientific investigations for the use of shallow low-enthalpy systems. Dissertation Nr. 15-519. ETH Zürich, Zurich, Switzerland. 